Portland State University

PDXScholar

$11-2000$

\title{
An Evaluation of Recidivism Rates for Resolutions Northwest's Victim-Offender Mediation Program
}

Karin Jewel Stone

Portland State University

Follow this and additional works at: https://pdxscholar.library.pdx.edu/open_access_etds

Part of the Public Affairs Commons, Public Policy Commons, and the Urban Studies Commons Let us know how access to this document benefits you.

\section{Recommended Citation}

Stone, Karin Jewel, "An Evaluation of Recidivism Rates for Resolutions Northwest's Victim-Offender Mediation Program" (2000). Dissertations and Theses. Paper 2291.

https://doi.org/10.15760/etd.2288

This Thesis is brought to you for free and open access. It has been accepted for inclusion in Dissertations and Theses by an authorized administrator of PDXScholar. For more information, please contact pdxscholar@pdx.edu. 


\section{THESIS APPROVAL}

The abstract and thesis of Karin Jewel Stone for the Master of Science in

Administration of Justice were presented November 3, 2000 and accepted by the thesis committee and the department.

COMMITTEE APPROVALS:
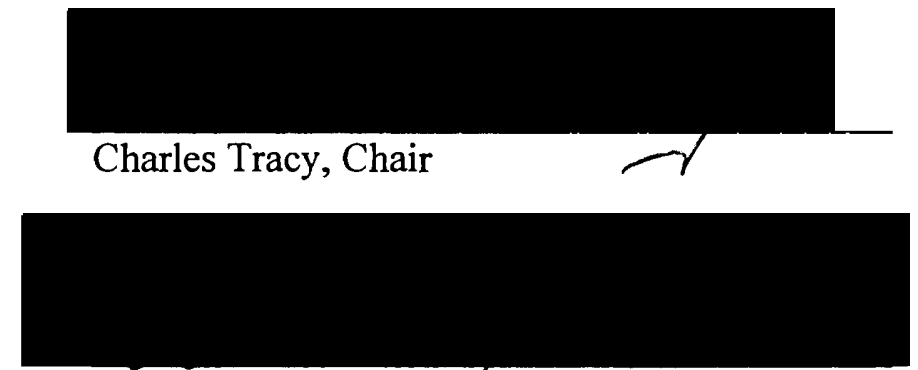

William Feyerherm

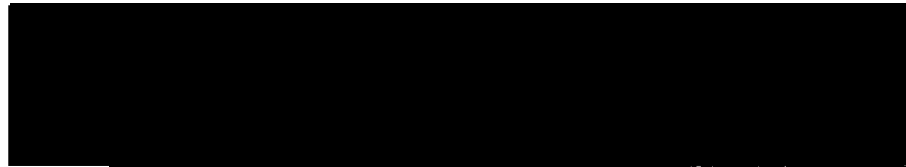

Charles Heying

DEPARTMENT APPROVAL:

Representative of the Office of Gradugte Studies

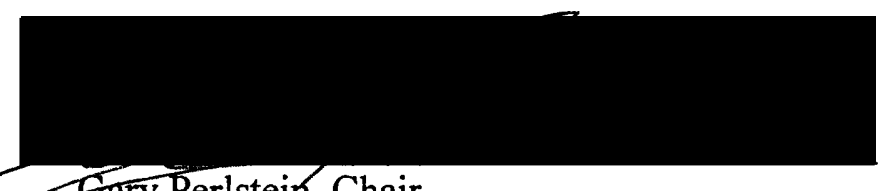

Gary Perlstein, Chair

Department of Administration of Justice 


\begin{abstract}
An abstract of the thesis of Karin Jewel Stone for the Master of Science in Administration of Justice presented November 3, 2000.
\end{abstract}

Title: An Evaluation of Recidivism Rates For Resolutions Northwest's VictimOffender Mediation Program

Victim-offender mediation, a component of restorative justice, has been a valuable tool for rehabilitating juvenile offenders since the late 1970 s. Victimoffender mediation brings crime victims and offenders together to reach agreements for restitution and community healing. Resolutions Northwest, a non-profit organization in Multnomah County, offers a victim-offender mediation program to juvenile offenders and their victims.

The purpose of this study was to analyze the recidivism rates for juvenile offenders who went through Resolutions Northwest's victim-offender mediation program as opposed to offenders who went through the traditional justice system. It was hypothesized that the participants in this program would have lower recidivism rates than the juvenile offenders who were not given this restorative justice option.

Records on juvenile offenders who successfully completed the victim-offender mediation program were collected from Resolutions Northwest. These records were then compared to a secondary data set. This secondary data was from the Tri-County Juvenile Information System database, supplied by the Multnomah County 
Department of Adult and Community Justice to Professor William Feyerherm as part of the Casey Foundation supported Juvenile Detention Alternative Initiative.

It was found that $41.6 \%$ of the Juvenile Detention Alternative Initiative group reoffended within one year of their original arrest. In comparison, only $20.3 \%$ of the Resolutions Northwest group reoffended within a year of their victim-offender mediation program completion. It was also investigated as to whether the juveniles in both groups reoffended a second, third or even fourth time within a one year period. The explorations into second, third and fourth reoffenses yielded similar results in that the juveniles from Resolutions Northwest had significantly lower recidivism rates than those from the Juvenile Detention Alternative Initiative group. 
AN EVALUATION OF RECIDIVISM RATES

FOR RESOLUTIONS NORTHWEST'S VICTIM-

OFFENDER MEDIATION PROGRAM

\author{
by \\ KARIN JEWEL STONE
}

A thesis submitted in partial fulfillment of the requirements for the degree of

\author{
MASTER OF SCIENCE \\ in \\ ADMINISTRATION OF JUSTICE
}

Portland State University

2000 


\section{Table of Contents}

List of Tables

Chapter 1: Resolutions Northwest Background Information

Chapter 2: Selected Literature Review

Chapter 3: A Report of Other Victim-Offender Mediation Studies

Chapter 4: Data Collection

Chapter 5: Findings and Discussion

Works Cited 28 33

ii .

4

7 


\section{$\underline{\text { List of Tables }}$}

Table 1: Resolutions Northwest Data - Frequency Distribution by Race

Table 2: Resolutions Northwest Data - Frequency Distribution by Gender

Table 3: Resolutions Northwest Data - Frequency Distribution by Residential Area of Juvenile

Page 35

Table 4: Frequency Distribution of Crimes Committed from 1996 to 1999 for Resolutions Northwest Juveniles

Table 5: Frequency Distribution of Crimes Committed in 1996 and 1997 for Resolutions Northwest Juveniles

Table 6: Frequency Distribution of Crimes Committed in 1996 and 1997 for Juvenile Detention Alternative Initiative Juveniles

Page 38

Table 7: 1st Recidivism within 1 year of Completion of Resolutions Northwest Victim-Offender Mediation Program - Frequency Distribution

Table 8: Frequency Distribution of 1st Recidivism within 1 year for Juvenile Detention Alternative Initiative Data

Table 9: 2nd Recidivism within 1 year of Completion of Resolutions Northwest Victim-Offender Mediation Program - Frequency Distribution

Table 10: Frequency Distribution of $2^{\text {nd }}$ Recidivism within 1 year for Juvenile Detention Alternative Initiative Data

Table 11: 3rd Recidivism within 1 year of Completion of Resolutions Northwest Victim-Offender Mediation Program - Frequency Distribution 
Table 12: Frequency Distribution of 3rd Recidivism within 1 year for Juvenile Detention Alternative Initiative Data

Table 13: 4th Recidivism within 1 year of Completion of Resolutions Northwest Victim Offender Mediation Program - Frequency Distribution

Page 48

Table 14: Frequency Distribution of 4th Recidivism within 1 year for Juvenile Detention Alternative Initiative Data

Table 15: Recidivism Rates for Resolutions Northwest (RNW) and Juvenile Detention Alternative Initiative (JDAI) Data

Table 16: Rates for Those Without Reoffenses from the Resolutions Northwest (RNW) and Juvenile Detention Alternative Initiative (JDAI) Data 


\section{Chapter 1}

\section{Resolutions Northwest Background Information}

Resolutions Northwest is a nonprofit restorative justice organization offering victim-offender mediation for crime victims and juvenile offenders. They have been in operation in Multnomah County (the Portland, Oregon Metropolitan area) since 1985. Some of the primary goals of this organization are to bring crime victims and juvenile offenders together to determine restitution to the victim and the community, to hold the youth accountable and to reduce crime.

Resolutions Northwest adheres to a co-mediation model (where two mediators go into a mediation session and work together) in their victim-offender mediation program. According to Sarah Othman, a Victim Offender Mediation Specialist at Resolutions Northwest, this model follows the national trend in similar programs. However, Resolutions Northwest also employs a cold mediation model. As indicated by Othman, this model consisting of mediators going into a mediation session with no background information on a case other than the names of both parties, the crime committed and the date of the crime is rare and not regularly practiced in the United States.

Resolutions Northwest is founded on the principles of accountability and responsibility. They are committed to strengthening personal and community responsibility by promoting constructive conflict resolution through mediation services, education and training. Their mediation services bring crime victims and juvenile offenders together to reach agreements for restitution and community healing. 
The fact that juvenile offenders often see themselves as victims is a guiding principle of Resolutions Northwest. Juveniles blame the system and are usually unaware of the impact their actions make on their victims. Most juvenile offenders do not get to see the hurt, fear, and/or anger that their actions can cause for victims.

Resolutions Northwest affords the opportunity to the juvenile to view the impact of his/her behavior. Through this vision, the youth can better accept responsibility for the crime committed. Through victim-offender mediation, victims' questions about the crime can be answered and a restitution agreement that meets the needs of both parties is created to bring closure to the incident.

The process of victim-offender mediation begins when a case is referred to Resolutions Northwest by the criminal justice system, a community agency, parents or other individuals. Cases are screened and the victims and offenders are contacted about the mediation process. If both parties agree, a mediation session is scheduled.

At the mediation session, the victim, the offender and two professionally trained mediators (many of whom are volunteers) meet to discuss the crime. Victims and offenders work toward developing empathy and understanding as they negotiate agreements to resolve the incident. Resolutions Northwest maintains contact with the victims and offenders until the terms of the contract have been fulfilled.

Resolutions Northwest lists victim empowerment, increased self-esteem for offenders, providing judges with an additional sentencing tool and saving thousands of tax dollars among the benefits of the victim-offender mediation program. Victim empowerment occurs by providing the opportunity to confront the offender. This 
allows a victim to have a voice, see that their needs are met and to gain closure.

Self-esteem is increased in an offender who gets to meet their victim. They are provided with a chance to learn to be accountable. They also gain self-esteem by accepting responsibility and completing their contract successfully.

The juvenile justice system benefits because judges have an additional and effective sentencing tool with which to respond to the needs of victims and the community. Also, avoiding juvenile court saves thousands of dollars of taxpayer money. According to Resolutions Northwest, their costs are under $\$ 300$. Resolutions Northwest has indicated in their brochure that juvenile court can cost upwards of $\$ 2,000$ or more to process an offender.

Resolutions Northwest's use of victim-offender mediation does appear to be beneficial. The aim of the research presented in this thesis is to determine whether juveniles who went through this process had a lower recidivism rate in the year following their program completion than juvenile offenders who went through the traditional adversarial justice system. First, the concept of victim-offender mediation and restorative justice will be explored in greater depth. 


\section{Chapter 2}

\section{Selected Literature Review}

Tony F. Marshall defines restorative justice as a problem-solving approach to crime in "Restorative Justice: an Overview." This approach involves the victim and offender and the community in an active relationship with statutory agencies. Marshall elaborates on this definition by stating that restorative justice is not a particular practice, but a set of principles, which may orientate the practice of any agency or group in relation to crime.

The principles listed in "Restorative Justice, an Overview" are as follows:

- Making room for the personal involvement of those mainly concerned (particularly the offender and the victim, but also their families and communities)

- Seeing crime problems in their social context

- A forward-looking (or preventative) problem-solving orientation

- Flexibility of practice (creativity).

"Restorative Justice, an Overview" also provides a list of restorative justice's general objectives. Marshall's objectives are:

- To attend fully to victims' needs - material, financial, emotional and social (including those who are personally close to the victim and may be similarly affected)

- To prevent re-offending by reintegrating offenders into the community

- To enable offenders to assume active responsibility for their actions 
- To recreate a working community that supports the rehabilitation of offenders and victims and is active in preventing crime

- To provide a means of avoiding escalation of legal justice and the. associated costs of delays.

Gordon Bazemore and Mark Umbreit offer a comparison of the current justice system and a restorative justice system in "Balanced and Restorative Justice for Juveniles: A Framework for Juvenile Justice in the $21^{\text {st }}$ Century." In the current justice system, performance objectives are met by the number of offenders who are incarcerated or detained. It is believed that recidivism will be reduced by deterrence or the threat of incarceration.

However, in a restorative justice system, the objectives are much deeper. One objective is to reduce recidivism, especially while offenders are under supervision in the community. Another objective is to increase citizens' feelings of safety and confidence in the juvenile justice system. Still another objective is to create community "guardians" and improve preventative capacities of schools, families and community agencies. It is also hoped that restorative justice will increase offender reintegration into the community and garner direct involvement of community members in the justice system.

According to Mara F. Schiff, a critical component of restorative justice is victim-offender mediation. In "Restorative Justice Interventions for Juvenile Offenders: A Research Agenda for the Next Decade," Schiff describes victimoffender mediation's design. The design is one that provides victims and offenders a 
chance to come together and communally agree on amends. The object is to deal with crime as a conflict to be resolved between the persons directly affected rather than as a conflict between the state and the accused.

The history of victim-offender mediation can be traced back to 1974. Mark Umbreit details this history in "Mediation of Criminal Conflict: An Assessment of Programs in Four Canadian Provinces." Ontario, Canada was the starting point of a now international justice process. Umbreit describes the history in detail as follows:

The origin of what is today known generically as the 'victim offender mediation' field... began many years ago in the Province of Ontario. In May of 1974, an experiment began in Elmira, a few miles north of Kitchener, Ontario, that would later trigger the international development of a new justice reform. Two young men pleaded guilty to twenty-two counts of property damage. Their probation officer and a colleague of his with the Mennonite Central Committee in Canada, had the vision and courage to try some basic peacemaking principles in resolving the conflict between these young men and the twenty-two people they victimized.

A recommendation was made to the court that these two offenders go back and meet every single person they victimized and assess how much loss occurred. The judge ordered a one month remand in order to allow these two young men to meet their victims, with the help of their probation officer and his colleague from the Mennonite Central Committee. After meeting with their victims and gaining a more human understanding of the impact of their criminal behavior, the judge sentenced them to probation and required them to pay restitution to the victims. Three months later, the offenders again visited each victim and handed them a cheque for the amount of his or her loss. (Umbreit, 1995, p. 1)

More information on the history of victim-offender mediation and how it spread from Canada is presented in "Mediation of Criminal Conflict in England: An Assessment of Services in Coventry and Leeds" by Mark Umbreit and Ann Warner Roberts. It started slowly to emerge in the United States and England in the late 
seventies and then began to branch out throughout the world in the following decades.

Umbreit and Roberts report the following on the growth and spread of victim-offender mediation:

The first replication of Victim Offender Reconciliation Project in the United States occurred in 1978 when the Mennonite Central Committee, probation staff, and a local judge in Elkhart, Indiana began accepting cases. In England, the first victim offender mediation project, as a police-based initiative, began in 1979 in Exeter, Devon... In both the U.S. and England, experimentation with the concept of mediation in a small number of cases (prior to any major initiative) actually began in the early to mid 1970s. In 1986, there were 12 projects in England and 47 in the United States. By the mid 1990s, there existed a network of approximately 20 projects in England, 150 victim offender mediation or reconciliation programs in the U.S., and 26 programs in Canada. The field has actually grown more rapidly in Europe, during recent years, with 20 projects in England, 54 in Norway, 40 in France, 293 in Germany, 130 in Finland, 8 in Belgium, and 1 in Scotland. (Umbreit and Rogers, 1996, p. 2)

Now that a brief history has been explored, it seems vital in delving into

victim-offender mediation to review how it is implemented within the justice system.

Gordon Bazemore and Mark Umbreit provide valuable information on victim-offender

mediation implementation in "Conferences, Circles, Boards, and Mediations:

Restorative Justice and Citizens Involvement in the Response to Youth Crime."

Bazemore and Umbreit describe the basics of victim-offender mediation below:

Cases may be referred to victim offender mediation programs by judges, probation officers, victim advocates, prosecutors, defense attorneys, and police. In some programs, cases are primarily referred as diversion from prosecution, assuming any agreement reached during the mediation session is successfully completed. In other programs, cases are usually referred after a formal admission of guilt has been accepted by the court, with mediation being a condition of probation (if the victim has volunteered to participate). Some programs receive case referrals at both stages. The majority of mediation sessions involve juvenile offenders, although the process 
is occasionally used with adults and even in very serious violent cases. In implementing any victim offender mediation program, it is critically important to maintain sensitivity to the needs of the victim. (Bazemore and Umbreit, 1998, p. 33)

Maria Volpe elaborates on victim-offender mediation in "Mediation in the

Criminal Justice System: Process, Promises, Problems." Volpe describes the many benefits of the mediation process. In her description of what she calls "the promise" of mediation, she writes: .

Central to the promise of mediation has been the improvement of the delivery of justice. Included among the benefits of using mediation have been the reduction of court backlogs, speedier processing of cases, availability of inexpensive services, empowerment of individuals and neighborhoods, and the opportunity for more appropriate forums than provided by the traditional legal adversarial system. By enabling disputants an opportunity to explore the underlying concerns and creative options, mediation offers them an opportunity to salvage relationships and live more peacefully. (Volpe, 1991, p. 199)

Mark Umbreit elaborates further into the benefits of victim-offender

mediation. Umbreit prepared a program evaluation kit for victim offender mediation programs. In the introduction to this valuable interview and question and answer kit, Umbreit makes the following statement regarding victim-offender mediation's value and benefits:

Victim-offender mediation and reconciliation programs provide an opportunity for those who commit criminal offenses to meet face-toface with the person they victimized, in the presence of a trained mediator. It is a conflict resolution process designed to be fair to both parties. The competency of the mediator is the most critical factor related to whether or not the parties have their informational, emotional and material needs met by the mediation process. (Umbreit, 1992, p. 1) 
While the competency of the mediator is critical, several other guidelines must be observed in order to ensure a positive victim-offender mediation experience. Mark Umbreit and Jean Greenwood give a multitude of guidelines in "Criteria for VictimSensitive Mediation and Dialogue with Offenders." One of the most important of these is victim safety. On this, Umbreit and Greenwood state:

A fundamental guideline for victim-offender mediation programs is the safety of the victim. The mediator must do everything possible to ensure that the victim will not be harmed in any way... To ensure the safety of the victim, the mediation should be conducted in a location that feels safe to the victim, and the victim should be encouraged to bring along a support person or two... In addition, the victims may find it reassuring to have input on the arrangement of the room and the seating of the parties, and to have the freedom to introduce themselves in the manner they choose, e.g. using first name only. (Umbreit and Greenwood, 1997, p. 3)

Umbreit and Greenwood also stress the importance of victim choice in "Criteria for Victim-Sensitive Mediation and Dialogue with Offenders." This refers not only to choosing to participate in a victim-offender mediation program, but also being involved in making choices throughout the process. Umbreit and Greenwood's elaboration on victim choice follows:

Following a crime, many victims experience vulnerability and feelings of powerlessness. Add to that the victim's experience with the criminal justice system, which is focused clearly on the offender. Victims are excluded from the process, rarely being offered an opportunity to tell of their experiences or express their needs. It is not surprising that in the wake of a crime, victims often express a lack of control in their lives, which can intensify their fear and anxiety. The presence of choices and options for the victim in the mediation process can contribute to a sense of power. Empowerment is conducive to healing, the capacity to move through and integrate difficult and painful experiences. The mediator provides information and support for the victim engaged in decision-making, but is careful not to apply any pressure or impose expectations on the victim. It is also important 
that victims have sufficient time to make decisions, without the pressure of arbitrary time constraints. (Umbreit and Greenwood, 1997, p. 4)

Umbreit and Greenwood continue on to highlight the importance of offender choice in victim-offender mediation in "Criteria for Victim-Sensitive Mediation and Dialogue with Offenders." This is integral to the process being seen in a positive light for both the offender and the victim. The following was written on the offender's choice in participation:

It is important that offenders participate voluntarily in mediation, throughout the entire process. Even when there exist certain pressures from the court system to participate, it must be made clear to offenders that they may, in fact, decline. If offenders mediate involuntarily, victims may experience the mediation as unsatisfactory and even harmful. The offender's attitude or insincerity may constitute an additional offense in the eyes of the victim. (Umbreit and Greenwood, 1997, p. 8)

Mark Umbreit and William Bradshaw provide more insight into the design of victim-offender mediation in "Victim Experience of Mediating Adult vs. Juvenile

Offenders: A Cross-National Comparison." These authors warn that victim-offender mediation should not be treated the same as other types of mediation. Their explanation follows:

Victim-offender mediation is different from other types of mediation. Mediation is being used in an increasing number of conflict situations, such as divorce and custody, community disputes, commercial disputes, and other civil court related conflicts. In such settings, the parties are called 'disputants,' with an assumption that they both are contributing to the conflict and therefore need to compromise to reach a settlement. Often, mediation in these settings is focused heavily upon reaching a settlement, with a lesser emphasis upon a discussion of the full impact of the conflict upon their lives. 
In victim-offender mediation, the involved parties are not 'disputants.' One clearly has committed a criminal offense and has admitted doing so. The other has clearly been victimized. Therefore, the issue of guilt or innocence is not mediated. Nor is there an expectation that crime victims compromise and request less than when they need to address their losses. While many other types of mediation are largely 'settlement driven,' victim-offender mediation is primarily 'dialogue driven,' with the emphasis upon victim healing, offender accountability, and restoration of losses. (Umbreit and Bradshaw, 1997, pp. 33-34)

Daniel Van Ness and Karen Heetderks Strong further illustrate the specialization of victim-offender mediation in Restoring Justice. The authors give a basic explanation, yet more specific to the justice system. On victimoffender mediation, they state the following:

...victims and offenders are given the opportunity to meet together with the assistance of a trained mediator to begin to resolve the conflict and to construct their own approach to achieving justice. Unlike the formal criminal justice system, which removes both the victim and the offender from proactive roles, these programs seek to empower the participants to resolve their own conflict on their own 'in an atmosphere of structured informality.' Unlike arbitration, in which a third party hears both sides and makes a judgment, the process relies on the victim and offender to resolve the dispute together. No specific outcome is imposed by the mediator; the goal is to empower participants, promote dialogue and encourage mutual problem solving. (Van Ness and Strong, 1997, pp. 69-70)

Clearly, this specialized type of mediation requires a strict level of sensitivity and professionalism for the mediator. In "the National Survey of Victim Offender Mediation Programs in the U.S.," Mark S. Umbreit and Jean Greenwood report on a study of victim-offender mediation that focuses on what qualities construct the most positive mediation environment. Parties previously involved in victim-offender 
mediation were asked to list what they believed were the most important tasks of a mediator.

As reported by Umbreit and Greenwood, there are four very popular responses to the question of what the most important mediator task is. The first and most popular response is that the mediator facilitates a dialogue between the victim and the offender. Obviously, nothing will be resolved if the victim and offender both sit at opposite sides of a table and simply stare at one another.

As the second most frequent answer, Umbreit and Greenwood state that the mediator should make both parties feel comfortable and safe. It is very important that the mediation environment does not feel hostile in any way. Both parties should feel safe to speak openly and that no additional harm will come to them physically or mentally.

The third response of the most important mediator tasks is that the mediator assists the parties in negotiating a restitution plan. It can be difficult for victims and juvenile offenders to decide what is a fair restitution. Often, they do not even know where to begin. A mediator helping to create a restitution plan can be extremely valuable to the mediation process.

Actively listening to both parties was shown to be the fourth highest response in important mediator tasks. The victim and offender do not want to feel that they are communicating alone. Knowing that an impartial listener is fully involved as the two parties engage in dialogue is integral to a successful mediation. 
Umbreit and Greenwood listed responses from their study that were less popular, yet are still very important in ensuring a smooth mediation process. Actively and effectively moving the parties toward a written agreement and getting out of the way so that the parties can talk directly to each other each garnered a moderate portion of responses. Other responses showed that participants would like the mediator to provide leadership, to reframe statements of the parties where helpful, and to actively paraphrase comments made by the parties.

Another important factor for consideration in victim-offender mediation is diversity. In "Multi-Cultural Implications of Restorative Justice: Potential Pitfalls and Dangers," Mark Umbreit and Robert Coates elaborate on how critical it is to take diversity issues into consideration. On this subject, they wrote:

Race, social economic status, ethnicity, gender, religion, sexual orientation, rural urban and many other defining characteristics will shape how an individual views the world and his or her place and chances in that world. Such will color whether there is a propensity to blame the offender, the victim, or the community for crime. Such will color whether participants come to a 'justice program' seeking revenge or seeking repair; desiring to act or desiring to be acted upon; expecting hope or expecting defeat. Chances for restoring justice can only be enhanced when those who work in justice programs make time, expend the energy, and take the risks of coming to understand themselves better regarding cultural understandings and misunderstandings. (Umbreit and Coates, 1998, pp. 6-7)

Umbreit and Coates are quick to point out that respecting diversity is a factor for both the mediator and the offenders and victims. Obviously, mediators should not bring prejudices to a mediation session. However, they need to be able to recognize when offenders and victims have pre-conceived notions that they are considering 
while in victim-offender mediation. In "Multi-Cultural Implications of Restorative. Justice: Potential Pitfalls and Dangers," this issue is expanded on as follows:

Program staff must not only examine their own beliefs and actions, but also must be alert to the imbedded racial biases of offender and victim. Racism may be a justification used by the offender for committing the crime. Racism may play into why and how the victim wants not an 'ounce of flesh,' but a 'pound of flesh.' Where racist assumptions or accusations are likely between offender and victim, the mediator will need to be prepared to act as an interpreter or buffer during premeetings and during any actual face-to-face encounters be they in the form of mediation, community boards, or other restorative justice programs. (Umbreit and Coates, 1998, pp. 7-8)

Umbreit and Coates also provide insight into the general implications of victim-offender mediation in "Victim Offender Mediation: An Analysis of Programs in Four States of the U.S." A two and a half year multi-site study provided valuable information on both justice policy implications and direct practice program implications.

The policy implications show that victim-offender mediation should be more consistently integrated into the large national network of court sponsored restitution programs. Strong evidence reportedly shows that victims of crime are more likely to be compensated if the restitution plan is negotiated by the offender and the victim. Victim-offender mediation should also receive more attention from victim advocacy groups, due to a victim's sense of vulnerabilitity and anxiety being reduced following a direct mediation session with their offender.

Umbreit and Coates state that wider public policy consideration should be given to increasing the availability of victim offender mediation services. This could be provided as a basic right for those victims of crime who would find it helpful. This 
is assuming that the offender agrees to such a meeting and a victim-offender mediation program is available.

Some of the program implications Umbreit and Coates have pointed to include insuring that mediation is voluntary, the training style of mediators and parents' involvement. In making sure that mediation is voluntary, additional attention should be paid to insuring that both parties fully agree to the mediation. Included in this should be training of case developers and mediators to inform both parties of all available options prior to their choice of mediation.

As for the training of mediators, it is believed that this should be enhanced to insure that appropriate non-directive style of mediation is used. This style includes the ability to make use of silence during mediation sessions and to avoid missing opportunities to encourage either the victim or the offender to address issues that are important to them. Umbreit and Coates believe that emphasis should be placed on demonstrated skill rather than simply completing a set number of hours of mediation training.

"Victim Offender Mediation: An Analysis of Programs in Four States of the U.S." also includes parents' roles within program implications. It is believed that the appropriate role of parents in the mediation process of juvenile offenders requires further clarification. Instead of developing policies that either include or do not include parents in the mediation session, Umbreit and Coates feel policies should be set up that involve specific circumstances where parents should be allowed in the entire mediation session. 
- Now that the concept of restorative justice, or more specifically, victimoffender mediation, has been explored in detail, information on other studies of victim-offender mediation programs seems valuable at this time. The following chapter will highlight key findings in many victim-offender mediation studies spanning from 1984 to 2000 . These studies extend across many different areas of the United States and Canada. The majority of the studies involve juvenile cases and range from minor property offenses to homicide. 
Chapter 3

\section{A Report of Other Victim-Offender Mediation Studies}

The University of Minnesota's Center for Restorative Justice and Peacemaking compiled the results of many victim-offender mediation studies in the first addition of "Research and Resources Review." Some of those results are interesting in reference to this study. This chapter will highlight some of these key results in other studies.

In 1984, J.P. Collins conducted a study of a victim-offender mediation program in Grand Prairie, Alberta, Canada. Interviews were conducted of the staff, victims, juvenile offenders, parents and community workers involved with this program. This study found that most involved believed that the process worked very well. The majority of participants walked away with a more positive view of the justice system and most believed their agreements had been fair and reasonable.

In 1986, A. Schneider studied records from a victim-offender mediation program in Washington, D.C. This study of juvenile offenders found there to be statistically significant lower recidivism rates for participants in this program than for those who wound up in probation. Therefore, it would seem that victim-offender mediation was more successful in the rehabilitation of juvenile offenders than probation was.

Mark Umbreit conducted a study in Minneapolis and St. Paul, Minnesota in 1988. From records interviews of victims and offenders, it was found that clients were typically satisfied. The findings showed that $93 \%$ of victims and a staggering $100 \%$ of offenders felt that their restitution agreements they had arrived at were fair. 
In 1989, Mark Umbreit conducted another study within the city of Minneapolis. In this study, 50 victims of burglary were interviewed. $62 \%$ of these victims went through victim-offender mediation. It was found that both the victims who went through victim-offender mediation and the ones who did not believed that victim participation is vital. It was also determined that $80 \%$ of the participants who went through victim-offender mediation believed they experienced fairness as opposed to only $38 \%$ of those who did not go through victim-offender mediation.

Mark Umbreit also conducted a study in Genesee County, New York and southern Wisconsin in 1989. Interviews with victims, offenders and mediators were performed. In this study, the crimes were more of a violent nature. Some of the cases involved were armed robbery, assault of a police officer, negligent homicide and a sniper shooting. Key findings of this study show that victims of violent crimes can benefit from face to face mediation assuming there is a significant amount of sensitivity throughout the process. This study also proves that victim-offender mediation that was developed for property crimes can be extended to work on cases dealing with violent crimes.

J. Gehm studied six victim-offender mediation programs in Indiana, Wisconsin, and Oregon in 1990. A total of 555 records were reviewed. In this research it was uncovered that victims and offenders were more likely to participate in victim-offender mediation if the offender was white, the offense was a misdemeanor and the victim was representing an institution and had not personally been harmed. 
In 1990, S. Hughes and A. Schneider looked at record surveys from restitution sites across the United States. They found that victim-offender mediation programs existed in counties with populations as low as 3,000 and ranging as high as 2 million. They discovered that the majority of programs were run by the private sector and that most participants were referred from courts. They also found that the majority of participants perceived victim-offender mediation to be functioning well and they believed they had experienced favorable outcomes.

Mark Umbreit conducted yet another study in the Minneapolis and St. Paul area of Minnesota in 1991. This study used both record data and interviews of 66 juvenile offenders and 51 victims. Key findings of this research were that $86 \%$ of victims reported it was helpful to meet the person who victimized them. An even higher number of offenders, $94 \%$, agreed that it was helpful to meet their victim.

In 1992, R. Coates and Mark Umbreit studied victim-offender mediation in Albuquerque, New Mexico, Minneapolis, Minnesota, Oakland, California, and Austin, Texas. Interviews and observations of 2,799 victims and 2,659 juvenile offenders showed that $79 \%$ of offenders and $87 \%$ of victims experienced high levels of satisfaction. This study also found that offenders who participate in victim-offender mediation are $81 \%$ more likely to complete agreements made than similar juvenile offenders who do not go through mediation. These youths show a $58 \%$ rate of agreement completion. It was also concluded that offenders and victims believed it was important to meet with one another and share pain and stories together. 
S. Clark, E. Valente, Jr., and R. Mace researched victim-offender mediation programs in three North Carolina counties in 1992. Record data and telephone interviews showed that agreements were reached in more than $90 \%$ of cases in these programs. All of the cases where agreements were reached were able to avoid going to trial. In one of the counties studied, the number of trials was actually reduced by a staggering two-thirds.

In 1993, S. Roy conducted a study in Elkhart, Indiana and Kalamazoo, Michigan. This study is interesting in that it reported no differences between victimoffender mediation and court-based restitution programs. The records of 218 juvenile offenders were reviewed. $50 \%$ of the youths were in face-to-face victim-offender mediation programs and $50 \%$ were in court-based restitution programs. No differences were found in either the rates of recidivism or the rate of completion of restitution contracts between the two groups.

W. Nugent and J. Paddock researched Anderson County, Tennessee records in 1995. In this study it was found that juveniles who go through victim-offender restitution programs are less likely to reoffend than those who went through regular juvenile court. It was also found that when the offenders from victim-offender restitution programs did reoffend, their crimes were less severe than the juveniles who had reoffended from the traditional justice system.

In 1995, Mark Umbreit conducted a study in Canada. Phone interviews, observation sessions, record review and personal interviews were undertaken in Langley, British Columbia, Calgary, Alberta, Winnipeg, Manitoba, and Ottawa, 
Ontario. Key findings in this study show that $78 \%$ of victims who participated in victim-offender mediation were satisfied with their outcomes. Only $48 \%$ of victims who did not go through mediation reported satisfaction. Also, $74 \%$ of offenders who went through victim-offender mediation were satisfied with their results as opposed to $53 \%$ of offenders who did not attend mediation sessions feeling satisfied.

Additionally, Umbreit reported in this study that mediation contributes to an enhanced sense of justice.

In 1996, C. Flaten conducted interviews with offenders, victims, victim's advocates, offender counselors and mediators in Anchorage, Alaska. This was an indepth study of seven serious-offense mediations, including manslaughter. Flaten found that six out of seven victims believed their mediation experience was successful. Conversely, offenders reported that they felt meeting the victim of their crime had personalized the crime event for them.

In Orange County, California, M. Niemeyer and D. Shichor conducted a questionnaire study in 1996. Although their recidivism results were mixed, they did find that agreements were reached in $99 \%$ of all mediated cases. It was also concluded that $70 \%$ of all victims and offenders chose face-to-face mediation if presented with the option.

In nearby Los Angeles County, California, research was conducted on victimoffender mediation programs in 1998. C. Carr used record data and interviews to conclude that juvenile offenders, parents and victims were highly satisfied with the results of mediation and believed mediators were fair. Almost all involved reported 
they were pleased that they had chosen to take part in victim-offender mediation and . said they would recommend the program to others. A six-month follow-up showed that $89 \%$ of the juvenile offenders who went through victim-offender mediation had not recidivated.

In 1998, L. Roberts researched 483 juvenile referrals, 196 victim-offender mediations and 189 agreements in Tucson, Arizona. Among Roberts' key findings was the fact that almost $90 \%$ of victims and offenders felt that it had been helpful to meet with the other party. It was also determined that $79 \%$ of juvenile offenders who had gone through victim-offender mediation had not recidivated within the year following mediation.

W. Bradshaw and Mark Umbreit did a secondary analysis of their 1992 study in California, Minnesota, New Mexico and Texas in 1998. Their intention was to find out what caused victim satisfaction within the mediation experience. Feeling good about the mediator, believing the restitution agreement to be fair and having a strong desire to meet the offender were reported as explanations of victim satisfaction in victim-offender mediation.

In 1999, Mark Umbreit and Jean Greenwood conducted nationwide telephone surveys. Some valuable, yet basic information on victim-offender mediation programs came from this study. It was discovered that juvenile offenders are referred to victimoffender mediation programs by judges at the rate of $23 \%$, by probation at the rate of $29 \%$ and by prosecutors at the rate of $15 \%$. Vandalism, minor assaults, thefts and burglaries made up the most frequent crimes committed by those referred to 
mediation. $34 \%$ of victim-offender mediation occurs as diversion and $56 \%$ occurs as post-adjudication. Of the victim-offender mediation programs in the United States, $81 \%$ take juvenile cases.

In 1999, W. Nugent, Mark Umbreit, L Wiinamaki and J. Paddock studied record data of juvenile offenders from four Tennessee counties, Minneapolis, Albuquerque, Austin and Oakland. Key findings from this study again showed that youth participating in victim-offender mediation are significantly less likely to recidivate than those who use more traditional methods. They also found that juveniles who do reoffend commit crimes of a much less serious nature when they went through victim-offender mediation programs.

The most recent research reported in Research and Resources Review was conducted in 2000. Mark Umbreit and Betty Vos conducted in-person interviews in Texas. In this highly sensitive study, two case studies involving mediation with death row inmates were looked at. Family members of victims of capital murders went through the victim-offender mediation process with the inmates serving time on death row for the murders. All of the participants involved expressed that they were very satisfied with the process of victim-offender mediation.

This concludes the summary of key research in many juvenile victim-offender mediation programs. As indicated in this chapter, a great majority of the results of previous research in this area have shone a positive light on victim-offender mediation in many parts of the country. The following chapters will present the process and 
results of similar research conducted on Multnomah County's Resolutions Northwest

program in Oregon. 


\section{Chapter 4}

\section{Data Collection}

Data was collected at Resolutions Northwest in Portland, Oregon.

Several thousand records were reviewed for the purposes of this research. Many records were discarded for varying reasons as outlined below. The final number of victim-offender mediation records that were acquired and used from Resolutions Northwest was 455 .

Since the goal of the research was to find out if a juvenile reoffended within one year, the records of several 18 year olds were discarded. Technically, an 18 year old is an adult in the legal system, but many 18 year olds were listed. This is probably due to the fact that the crime they committed occurred just before they turned 18 , but they were 18 years old while going through the Resolutions Northwest victim-offender mediation program. Once a juvenile has legally become an adult, Resolutions

Northwest no longer has tracking capabilities of their criminal record. For this reason, the records of 18 year olds were not used.

Due to the necessity of finding which juveniles had recidivated within a year of completing Resolutions Northwest's victim-offender mediation program, records from the year 2000 were also discarded. Obviously, Resolutions Northwest did not have data as to which juveniles reoffended in 2001 when the research was conducted in 2000. Since the juveniles who were going through Resolutions Northwest's victimoffender mediation program during this research project in 2000 still had time to recidivate, these records were thrown out. 
For the purpose of keeping the data set manageable, records prior to 1996 were not used. Not using records prior to 1996 also seemed like a reasonable data acquisition plan due to the fact that Resolutions Northwest has been changing and improving since their inception in 1985. It seemed logical to track their more recent participants rather than to focus on outcomes from the too distant past.

Records in which participants did not successfully complete the victimoffender mediation program were also discarded. Assuming that going through a victim-offender mediation program would have an effect on recidivism, it would seem that those who failed to complete the program should be excluded. If either the offender or the victim did not want to participate or if one of the participants failed to show up for the mediation, then the goals of victim-offender mediation were not accomplished. If a juvenile offender does not complete the program, then it cannot be determined whether or not the victim-offender mediation program caused an effect on recidivism.

To sum up, the 455 Resolutions Northwest records that were used for this research were taken from the years 1996 to 1999 . They involved juveniles 17 years of age and younger. They also only involved completed victim-offender mediations. The specific information gathered from each record is as follows:

- Age

- Race

- Gender 
- The Original Crime Committed (that caused referral to Resolutions ${ }^{\circ}$ Northwest)

- The Date the Juvenile was Referred to Resolutions Northwest .

- The Date of the Victim-Offender Mediation Meeting

- The Date of Completion, or Date the File was Closed

- The Area of Multnomah County the Juvenile was From

The above information was compiled from each of the 455 records. The task at hand was then to determine which of the juveniles reoffended within a one-year period of program completion. Each of the 455 juveniles was looked up on the Juvenile Information Network (JN). It was then recorded for each youth whether or not there was a reoffense.

If there was a reoffense, then the specific crime(s) and the date(s) the crime was committed within the year following Resolutions Northwest completion were recorded. For the purpose of this research, status offenses were excluded. Only offenses that would be illegal should they be committed by adults were included in this research. Traffic offenses were also not considered in recidivism rates.

The Resolutions Northwest data was then compared to another set of data. This additional set of data was secondary data provided by Professor William $\mathrm{H}$. Feyerherm. This data is from the TЛS (Tri-County Juvenile Information System) database, supplied by the Multnomah County Department of Adult and Community Justice to Professor Feyerherm as part of the Casey Foundation supported Juvenile Detention Alternative Initiative. 
There were 73,658 records in the Juvenile Detention Alternative Initiative • dataset. These records spanned from 1990 to 1997. Since the Resolutions Northwest dataset spans from 1996 to 1999 , only records from 1996 and 1997 were used from the Juvenile Detention Alternative Initiative data. Therefore, in comparisons between the two data groups, only the records from 1996 and 1997 are used in the Resolutions Northwest data, as well.

It also was necessary to eliminate many of the records from the Juvenile Detention Alternative Initiative data due to the nature of the crimes the youths had committed. Only records with the same original offenses that juveniles had committed in the Resolutions Northwest data were used. It seems to make sense that a juvenile who commits a homicide should not be compared to a juvenile who commits an act of vandalism for recidivism purposes. Therefore, both datasets contain the following original offenses:

- Criminal Trespass II, Class C Misdemeanor

- Theft III, Class C Misdemeanor

- Harassment, Class B Misdemeanor

- Assault IV, Class A Misdemeanor

- Attempted Burglary II, Class A Misdemeanor

- Criminal Mischief II, Class A Misdemeanor

- Forgery II, Class A Misdemeanor

- Menacing, Class A Misdemeanor

- Theft II, Class A Misdemeanor 
- Assault III, Class C Felony

- Burglary II, Class C Felony

- Criminal Mischief I, Class C Felony

- Forgery I, Class C Felony

- Fraudulent Use of a Credit Card, Class C Felony

- Theft I, Class C Felony

- Unauthorized Use of a Motor Vehicle, Class C Felony

- Burglary I, Class A Felony

These were the crimes originally committed that caused the juvenile to be processed into the juvenile justice system or to be referred to Resolutions Northwest. However, reoffenses of any type that occurred within one year are recorded in both sets of data. Only records where reoffenses were limited to status and/or traffic offenses were removed from either set of data.

Many of the Juvenile Detention Alternative Initiative data records had duplicate case ID numbers. It was not ideal to count the same juvenile twice. This is because if they did not reoffend within a year, it would appear that two or more juveniles had not reoffended, depending on their number of records.

Therefore, multiple records belonging to the same offender were removed so that each juvenile was only represented one time. This was done by leaving only the first record or the last record, alternating between each juvenile. The final number of records used from the Juvenile Detention Alternative Initiative data after all of these removals was 4,442 . 


\section{Chapter 5}

\section{Findings and Discussion}

The first section of Chapter 5 will focus on the Resolutions Northwest data only. A variety of frequency distributions were run on various variables within the 455 Resolutions Northwest records. To begin, Table 1 shows a breakdown of the juveniles who went through the Resolutions Northwest victim-offender mediation program by their race.

Resolutions Northwest Data - Frequency Distribution by Race

\begin{tabular}{|rrrrr|}
\hline & Frequency & Percent & Valid Percent & Cumulative \\
& & & & Percent \\
African American & 60 & 13.2 & 13.2 & 13.2 \\
Asian American & 16 & 3.5 & 3.5 & 16.7 \\
Hispanic & 25 & 5.5 & 5.5 & 22.2 \\
Native American & 1 & .2 & .2 & 22.4 \\
White, Non-Hispanic & 344 & 75.6 & 75.6 & 98.0 \\
Other/No Data & 9 & 2.0 & 2.0 & 100.0 \\
Total & 455 & 100.0 & 100.0 & \\
\hline
\end{tabular}

Clearly, the majority (75.6\%) of juveniles who are referred to Resolutions Northwest are white. This may be simply attributed to the fact that the majority of Multnomah County is comprised of white people. It may be possible that racism is put into effect and that white juveniles are more likely to be referred to an alternative program that gives youth a second chance than minority offenders are. There is no evidence to support that statement in this research, however.

African American youths made up 13.2\% of the Resolutions Northwest data. Hispanics comprise the next largest group making up 5.5\% of this research's 
population. Both Asian Americans and Native Americans make up a rather insignificant percentage of the Resolutions Northwest data, equating to $3.5 \%$ and $.2 \%$ of the dataset respectively.

Table 2 below shows the Resolutions Northwest data with a breakdown of gender. As the table shows, the vast majority $(80 \%)$ of juvenile offenders who go through Resolutions Northwest's victim-offender mediation program are boys. Girls comprised only $20 \%$ of the juvenile offenders. Unfortunately, this research does not show whether more males are referred to Resolutions Northwest than females or if it is simply a matter of boys committing more criminal offenses than girls.

Resolutions Northwest Data - Frequency Distribution by Gender

\begin{tabular}{|rrrrr|}
\hline & Frequency & Percent Valid Percent & Cumulative \\
Male & & & & Percent \\
Female & 364 & 80.0 & 80.0 & 80.0 \\
Total & 91 & 20.0 & 20.0 & 100.0 \\
\hline
\end{tabular}

Table 3 shows the Resolutions Northwest data categorized by the different residential areas that the juvenile offenders lived in. Although Multnomah County is comprised of several cities, $79.1 \%$ of the offenders hailed from Portland, Oregon. $70.1 \%$ of the offenders came from the east side of the city, which is made up of North, Northeast and Southeast Portland. Southeast Portland contained the highest percentage of records overall, comprising $32.5 \%$ of the dataset.

Enough of Resolutions Northwest's juveniles resided in the other cities within Multnomah County (and a few out of the county) to make up a small portion of the dataset. Gresham, Oregon was the hometown of $9.9 \%$ of the offenders. There was 
also a small percentage of the population (2.2\%) who hailed from "East County," which is a term that could refer to either the far eastern portion of Portland or the western portion of Gresham. Table 3 below shows a more extensive breakdown.

Resolutions Northwest Data - Frequency Distribution by Residential Area of Juvenile

\begin{tabular}{rrrrr|}
\hline & Frequency & Percent & Valid Percent & Cumulative \\
North Portland & 56 & 12.3 & 12.3 & Percent \\
Northeast Portland & 115 & 25.3 & 25.3 & 37.6 \\
Southeast Portland & 148 & 32.5 & 32.5 & 70.1 \\
Southwest Portland & 30 & 6.6 & 6.6 & 76.7 \\
Northwest Portland & 11 & 2.4 & 2.4 & 79.1 \\
Gresham & 45 & 9.9 & 9.9 & 89.0 \\
East County, City Unknown & 10 & 2.2 & 2.2 & 91.2 \\
Corbett & 6 & 1.3 & 1.3 & 92.5 \\
Troutdale & 9 & 2.0 & 2.0 & 94.5 \\
Fairview & 4 & .9 & .9 & 95.4 \\
Sherwood & 1 & .2 & .2 & 95.6 \\
Canby & 1 & .2 & .2 & 95.8 \\
Milwaukie & 2 & .4 & .4 & 96.3 \\
Forest Grove & 2 & .4 & .4 & 96.7 \\
Vancouver, WA & 2 & .4 & .4 & 97.1 \\
Beaverton & 1 & .2 & .2 & 97.4 \\
Hillsboro & 1 & .2 & .2 & 97.6 \\
West Linn & 1 & .2 & .2 & 97.8 \\
Other/No Data & 10 & 2.2 & 2.2 & 100.0 \\
Total & 455 & 100.0 & 100.0 & \\
\hline & & & & Table 3
\end{tabular}

As was reported in Chapter 4, only certain offenses are contained within the Resolutions Northwest data. Although they are listed in the previous chapter, Table 4 shows the percentage that each of the crimes appeared within the dataset. Criminal Mischief I proves to be the crime most often committed (31.4\%) by juvenile offenders who are referred to Resolutions Northwest. Unauthorized Use of a Motor Vehicle and Burglary II were the second and third most frequent offenses comprising $18.7 \%$ and $17.1 \%$ of the data respectively. Table 4 shows the breakdown of Resolutions 
Northwest offenses with much greater detail.

Frequency Distribution of Crimes Committed from 1996 to 1999 for Resolutions Northwest Juveniles

\begin{tabular}{|c|c|c|c|c|}
\hline & Frequency & Percent & $\begin{array}{r}\text { Valid } \\
\text { Percent }\end{array}$ & $\begin{array}{r}\text { Cumulativ } \\
\text { Percen }\end{array}$ \\
\hline Unknown & 15 & 3.3 & 3.3 & \\
\hline Criminal Trespass II & 6 & 1.3 & 1.3 & \\
\hline Harassment & 2 & .4 & .4 & \\
\hline Theft III & 2 & .4 & .4 & \\
\hline Theft II & 17 & 3.7 & 3.7 & \\
\hline Forgery II & 1 & .2 & .2 & \\
\hline Criminal Mischief II & 30 & 6.6 & 6.6 & \\
\hline Menacing & 1 & .2 & .2 & \\
\hline Burglary II, Attempted & 3 & .7 & .7 & \\
\hline Assault IV & 7 & 1.5 & 1.5 & \\
\hline Fraudulent Use of a Credit Card & 2 & .4 & .4 & \\
\hline Theft I & 51 & 11.2 & 11.2 & \\
\hline Unauthorized Use of a Motor Vehicle & 85 & 18.7 & 18.7 & \\
\hline $\begin{array}{ll}\text { Forgery I }\end{array}$ & 6 & 1.3 & 1.3 & \\
\hline Criminal Mischief I & 143 & 31.4 & 31.4 & \\
\hline Burglary II & 78 & 17.1 & 17.1 & \\
\hline Assault III & 4 & .9 & .9 & \\
\hline Burglary I & 2 & .4 & .4 & \\
\hline Total & 455 & 100.0 & 100.0 & \\
\hline
\end{tabular}

Table 5 provides essentially the same breakdown as Table 4 . However, Table 5 isolates the offenses from the Resolutions Northwest data that occurred in 1996 and 1997. This reduces the total number of Resolutions Northwest records to 251. Again, this is for the purposes of comparing the Resolutions Northwest data to the Juvenile Detention Alternative Initiative data that only goes through 1997.

The Resolutions Northwest offenses in 1996 and 1997 show roughly the same offenses being committed with similar frequency. In this breakdown, Criminal Mischief I again makes up the largest portion of the data, comprising $34.7 \%$ of all offenses. In isolating 1996 and 1997 from the overall Resolutions Northwest data, 
Burglary II moved to second place making up $20.3 \%$ of crimes committed and ' Unauthorized Use of a Motor Vehicle came in third by contributing to $16.7 \%$ of crimes. Table 5 below provides a more detailed analysis.

Frequency Distribution of Crimes Committed in 1996 and 1997 for Resolutions Northwest Juveniles

\begin{tabular}{rrrrr|}
\hline & Frequency & Percent & \multicolumn{2}{c|}{ Valid } \\
& & & Cumulative \\
Crime Unknown & 6 & 2.4 & 2.4 & Percent \\
Criminal Trespass II & 5 & 2.0 & 2.0 & 4.4 \\
Harassment & 1 & .4 & .4 & 4.8 \\
Theft III & 3 & 1.2 & 1.2 & 6.0 \\
Forgery II & 1 & .4 & .4 & 6.4 \\
Criminal Mischief II & 22 & 8.8 & 8.8 & 15.1 \\
Burglary II, Attempted & 3 & 1.2 & 1.2 & 16.3 \\
Assault IV & 3 & 1.2 & 1.2 & 17.5 \\
Theft I & 21 & 8.4 & 8.4 & 25.9 \\
Forgery I & 42 & 16.7 & 16.7 & 42.6 \\
Unauthorized Use of a Motor Vehicle & 3 & 1.2 & 1.2 & 43.8 \\
Criminal Mischief I & 87 & 34.7 & 34.7 & 78.5 \\
Burglary II & 51 & 20.3 & 20.3 & 98.8 \\
Assault III & 3 & 1.2 & 1.2 & 100.0 \\
Total & 251 & 100.0 & 100.0 & \\
\hline & & & & Table 5
\end{tabular}

Although the same offenses are represented in both the Resolutions Northwest and the Juvenile Detention Alternative Initiative datasets, the frequency the same crimes were committed is quite different. Table 6 displays this fact in a more detailed manner. According to the Juvenile Detention Alternative Initiative data, the crime committed with the greatest frequency by juveniles in 1996 and 1997 was Theft III, which is a theft of less than $\$ 50.00$. Theft III accounted for $18.4 \%$ of the data.

Theft II came in a close second, making up $16.7 \%$ of the dataset. Assault IV was third comprising only $12.0 \%$ of the population. Interestingly, Criminal Mischief I, Unauthorized Use of a Motor Vehicle, and Burglary II (the most frequent offenses 
in the Resolutions Northwest data) only made up a small fraction of the Juvenile

Detention Alternative Initiative data. They garnered $5.0 \%, 8.8 \%$ and $4.0 \%$ of the data respectively. Table 6 below provides this information and more with greater detail.

Frequency Distribution of Crimes Committed in 1996 and 1997 for Juvenile Detention Alternative Initiative Juveniles

\begin{tabular}{rrrrr}
\hline & Frequency & Percent & \multicolumn{2}{c}{ Valid } \\
& & & Cumulative \\
Cercent & Percen \\
Criminal Trespass II & 269 & 6.1 & 6.1 & 6.1 \\
Harassment & 163 & 3.7 & 3.7 & 9.7 \\
Theft III & 817 & 18.4 & 18.4 & 28.1 \\
Theft II & 744 & 16.7 & 16.7 & 44.9 \\
Forgery II & 26 & .6 & .6 & 45.5 \\
Criminal Mischief II & 338 & 7.6 & 7.6 & 53.1 \\
Menacing & 150 & 3.4 & 3.4 & 56.4 \\
Burglary II, Attempted & 2 & .0 & .0 & 56.5 \\
Assault IV & 533 & 12.0 & 12.0 & 68.5 \\
Theft I & 137 & 3.1 & 3.1 & 71.6 \\
Unauthorized Use of a Motor Vehicle & 391 & 8.8 & 8.8 & 80.4 \\
Forgery I & 26 & .6 & .6 & 81.0 \\
Criminal Mischief I & 223 & 5.0 & 5.0 & 86.0 \\
Burglary II & 176 & 4.0 & 4.0 & 89.9 \\
Assault III & 232 & 5.2 & 5.2 & 95.2 \\
Burglary I & 215 & 4.8 & 4.8 & 100.0 \\
Total & 4442 & 100.0 & 100.0 & \\
\hline
\end{tabular}

The main goal of this thesis was to discover whether or not juvenile offenders who went through Resolutions Northwest's victim-offender mediation program had a lower recidivism rate than youths who went through the traditional justice system. Table 7 provides complete information on the recidivism rates of the Resolutions Northwest juveniles. Both the number of offenders who did not recidivate and the number of offenders who did reoffend (broken down by the crime the youth committed within the year following victim-offender mediation) are shown in detail in Table 7. 
1st Recidivism within 1 year of Completion of Resolutions Northwest Victim-

Offender Mediation Program - Frequency Distribution

\begin{tabular}{|c|c|c|c|c|}
\hline & Frequency & Percent & $\begin{array}{r}\text { Valid } \\
\text { Percent }\end{array}$ & $\begin{array}{r}\text { Cumulative } \\
\text { Percen }\end{array}$ \\
\hline No Recidivism & 200 & 79.7 & 79.7 & \\
\hline Criminal Mischief III & 2 & .8 & .8 & \\
\hline Theft III & 6 & 2.4 & 2.4 & \\
\hline Theft II & 7 & 2.8 & 2.8 & \\
\hline Criminal Mischief II & 2 & .8 & .8 & \\
\hline Criminal Trespass I & 1 & .4 & .4 & \\
\hline Assault IV & 9 & 3.6 & 3.6 & \\
\hline Theft I & 3 & 1.2 & 1.2 & \\
\hline Unauthorized Use of a Motor Vehicle & 5 & 2.0 & 2.0 & \\
\hline Criminal Mischief I & 4 & 1.6 & 1.6 & \\
\hline Burglary II & 2 & .8 & .8 & \\
\hline Assault III & 2 & .8 & .8 & \\
\hline Arson I, Attempted & 1 & .4 & .4 & \\
\hline Assault II & 1 & .4 & .4 & \\
\hline Robbery II & 1 & .4 & .4 & 98 \\
\hline Burglary I & 4 & 1.6 & 1.6 & 99 \\
\hline Robbery I & 1 & .4 & .4 & 100 \\
\hline Total & 251 & 100.0 & 100.0 & \\
\hline
\end{tabular}

As Table 7 above shows, $79.7 \%$ of the juvenile offenders who participated in

the Resolutions Northwest victim-offender mediation program did not reoffend within one year of program completion. As Table 8 below shows, $58.4 \%$ of the offenders who went through the traditional justice system did not reoffend within a one year period. This does show that Resolutions Northwest offenders have a lower recidivism rate than juveniles who went through the traditional justice system.

Frequency Distribution of 1st Recidivism within 1 year for Juvenile Detention Alternative Initiative Data (Table 8)

\begin{tabular}{|rrrrr|}
\hline & Frequency & Percent & \multicolumn{2}{c|}{ Valid } \\
& & & Percent & Percent \\
No Recidivism & 2594 & 58.4 & 58.4 & 58.4 \\
Probation Violation & 216 & 4.9 & 4.9 & 63.3 \\
\hline
\end{tabular}


Frequency Distribution of 1st Recidivism within 1 year for Juvenile Detention Alternative Initiative Data (Table 8) Continued

Valid Cumulative

\begin{tabular}{|c|c|c|c|c|}
\hline & Frequency & Percent & Percent & Percent \\
\hline Physical Abuse & 1 & .0 & .0 & . 63. \\
\hline Ordinance Violation & 3 & .1 & .1 & 63. \\
\hline Illegal Discharge of a Firearm & 1 & .0 & .0 & 63. \\
\hline $\begin{array}{r}\text { Entering a Motor Vehicle w/out Owner's } \\
\text { Consent }\end{array}$ & 2 & .0 & .0 & 63. \\
\hline Unlawful Application of Graffiti & 2 & .0 & .0 & 63. \\
\hline $\begin{array}{r}\text { Possession of Less than } 1 \mathrm{Oz} \text {. of } \\
\text { Marijuana }\end{array}$ & 23 & .5 & .5 & 64. \\
\hline $\begin{array}{r}\text { Unlawful Possession of a Weapon - } \\
\text { Misdemeanor }\end{array}$ & 18 & .4 & .4 & 64. \\
\hline Carrying a Concealed Weapon & 10 & .2 & .2 & 64. \\
\hline Offensive Littering & 7 & .2 & .2 & 64. \\
\hline False Information to Police & 14 & .3 & .3 & 65. \\
\hline Initiating a False Report & 3 & .1 & .1 & 65. \\
\hline Criminal Trespass II & 112 & 2.5 & 2.5 & 67. \\
\hline Criminal Mischief III & 24 & .5 & .5 & 68. \\
\hline $\begin{array}{r}\text { Possession of Less than } 1 \mathrm{Oz} \text {. of } \\
\text { Marijuana in Public }\end{array}$ & 4 & .1 & .1 & 68. \\
\hline Animal Abuse II & 1 & .0 & .0 & 68. \\
\hline Harassment & 41 & .9 & .9 & 69. \\
\hline Disorderly Conduct & 24 & .5 & .5 & 69. \\
\hline Obstructing Government Administration & 2 & .0 & .0 & 69. \\
\hline Theft of Services & 4 & .1 & .1 & 69. \\
\hline Theft III & 161 & 3.6 & 3.6 & 73. \\
\hline Theft II & 168 & 3.8 & 3.8 & 77. \\
\hline Escape II, Attempted & 1 & .0 & .0 & 77. \\
\hline Forgery II & 10 & .2 & .2 & 77. \\
\hline Possession of Burglar's Tools & 2 & .0 & .0 & 77. \\
\hline Providing Alcohol to Person under 21 & 2 & .0 & .0 & 77. \\
\hline $\begin{array}{r}\text { Criminal Possession of a Forgery } \\
\text { Instrument II }\end{array}$ & 3 & .1 & .1 & 77. \\
\hline Resisting Arrest & 4 & .1 & .1 & 77. \\
\hline Reckless Burning & 2 & .0 & .0 & 77. \\
\hline Criminal Mischief II & 93 & 2.1 & 2.1 & 80. \\
\hline $\begin{array}{r}\text { Unauthorized Use of a Motor Vehicle - } \\
\text { Attempted }\end{array}$ & 5 & .1 & .1 & 80. \\
\hline Criminal Trespass I & 21 & .5 & .5 & 80. \\
\hline .. Menacing & 44 & 1.0 & 1.0 & 81. \\
\hline Assaulting a Public Safety Officer & 3 & .1 & .1 & 81. \\
\hline
\end{tabular}

Table 8 Continued on the Next Page 
Frequency Distribution of 1st Recidivism within 1 year for Juvenile Detention Alternative Initiative Data (Table 8) Continued

Valid Cumulative

\begin{tabular}{|c|c|c|c|c|}
\hline & & & & \\
\hline Fraudulent Use of Credit Card & 1 & .0 & .0 & .81 .6 \\
\hline Unlawful Entry into a Motor Vehicle & 3 & .1 & .1 & 81.7 \\
\hline Recklessly Endangering Another Person & 11 & .2 & .2 & 81.9 \\
\hline Robbery III, Attempted & 1 & .0 & .0 & 82.0 \\
\hline Theft I, Attempted & 2 & .0 & .0 & \\
\hline Intimidation II & 2 & .0 & .0 & \\
\hline Criminal Conspiracy IV & 5 & .1 & .1 & 82 \\
\hline Assault IV & 150 & 3.4 & 3.4 & \\
\hline Assault III, Attempted & 1 & .0 & .0 & 8 \\
\hline Sexual Abuse III & 2 & .0 & .0 & \\
\hline $\begin{array}{r}\text { Unlawful Possession of a Weapon - } \\
\text { Felony }\end{array}$ & 5 & .1 & .1 & \\
\hline $\begin{array}{r}\text { Criminal Possession of a Forgery } \\
\text { Instrument I }\end{array}$ & 1 & .0 & .0 & \\
\hline Theft I & 38 & .9 & .9 & 86 \\
\hline Possession of a Stolen Motor Vehicle & 7 & .2 & .2 & 86 \\
\hline Unauthorized Use of a Motor Vehicle & 115 & 2.6 & 2.6 & \\
\hline $\begin{array}{ll}\text { Forgery I }\end{array}$ & 10 & .2 & .2 & \\
\hline Criminal Mischief I & 62 & 1.4 & 1.4 & \\
\hline Unlawful Use of a Weapon & 6 & .1 & .1 & 91 \\
\hline Carrying a Loaded Weapon in a Public & 4 & .1 & .1 & 91 \\
\hline Place & & & & \\
\hline Burglary II & 55 & 1.2 & 1.2 & 92 \\
\hline Tampering With a Witness & 2 & .0 & .0 & 92 \\
\hline Criminal Conspiracy III & 4 & .1 & .1 & \\
\hline Riot & 2 & .0 & .0 & \\
\hline Intimidation I & 3 & .1 & .1 & \\
\hline Robbery III & 18 & .4 & .4 & 93 \\
\hline $\begin{array}{ll}\text { Assault III }\end{array}$ & 55 & 1.2 & 1.2 & 94 \\
\hline Possession of a Controlled Substance I & 3 & .1 & .1 & 94 \\
\hline Possession of a Controlled Substance II & 22 & .5 & .5 & 94 \\
\hline Possession of a Controlled Substance III & 1 & .0 & .0 & \\
\hline Delivery of a Controlled Substance II & 30 & .7 & .7 & \\
\hline $\begin{array}{r}\text { Creation of Delivery of a Controlled } \\
\text { Substance II }\end{array}$ & 1 & .0 & .0 & \\
\hline Delivery of a Controlled Substance I & 9 & .2 & .2 & 95 \\
\hline Escape I & 2 & .0 & .0 & 95 \\
\hline Burglary I, Attempted & 7 & .2 & .2 & 96 \\
\hline Arson I, Attempted & 4 & .1 & .1 & \\
\hline
\end{tabular}

Table 8 Continued on the Next Page 
Frequency Distribution of 1st Recidivism within 1 year for Juvenile Detention * Alternative Initiative Data (Table 8) Continued

\begin{tabular}{|rrrrr|} 
& & \multicolumn{2}{c}{ Valid Cumulative } \\
& Frequency & Percent & Percent & Percent \\
Assault II & 14 & .3 & .3 & 96.4 \\
Robbery II & 21 & .5 & .5 & 96.9 \\
Sexual Abuse I & 5 & .1 & .1 & 97.0 \\
Minor & 9 & .2 & .2 & 97.2 \\
Delivering a Controlled Substance to a & & & & \\
Burglary II & 93 & 2.1 & 2.1 & 99.3 \\
Arson I & 5 & .1 & .1 & 99.4 \\
Sexual Penetration w/ a Foreign Object I & 1 & .0 & .0 & 99.4 \\
Sodomy I & 2 & .0 & .0 & 99.5 \\
Assault I & 3 & .1 & .1 & 99.5 \\
Robbery I & 8 & .2 & .2 & 99.7 \\
Kidnapping I & 1 & .0 & .0 & 99.8 \\
Rape I & 3 & .1 & .1 & 99.8 \\
Criminal Conspiracy I & 7 & .2 & .2 & 100.0 \\
Murder, Homicide & 1 & .0 & .0 & 100.0 \\
Total & 4442 & 100.0 & 100.0 & \\
\hline
\end{tabular}

Both sets of data took into account whether or not offenders recidivated and what crimes were committed as reoffenses. Tables 7 and 8 both show these crimes in their entirety. However, some of the juvenile offenders in both datasets had multiple reoffenses.

Tables 7 and 8 only show the first offense committed within one year for those who reoffended. Table 9 looks at those who committed a second offense within a year of completion of the Resolutions Northwest victim-offender mediation program. Here it is shown that $93.6 \%$ of the Resolutions Northwest juvenile offenders were not charged with a second crime. Table 10 , which follows Table 9 , shows that $81 \%$ of the offenders in the Juvenile Detention Alternative Initiative dataset were not charged with a second offense. 
2nd Recidivism within 1 year of Completion of Resolutions Northwest VictimOffender Mediation Program - Frequency Distribution

\begin{tabular}{|rrrrr|}
\hline & Frequency & Percent & Valid Percent & Cumulative Percen \\
No Recidivism & 235 & 93.6 & 93.6 & 93. \\
Harassment & 2 & .8 & .8 & 94. \\
Theft III & 2 & .8 & .8 & 95. \\
Criminal Mischief II & 1 & .4 & .4 & 95. \\
Menacing & 1 & .4 & .4 & 96. \\
Assault IV & 4 & 1.6 & 1.6 & 97. \\
Theft I & 1 & .4 & .4 & 98. \\
Forgery I & 1 & .4 & .4 & 98. \\
Criminal Mischief I & 2 & .8 & .8 & 99. \\
Burglary II & 1 & .4 & .4 & 99. \\
Burglary I & 1 & .4 & .4 & 100. \\
Total & 251 & 100.0 & 100.0 & \\
\hline
\end{tabular}

Table 9

Frequency Distribution of $2^{\text {nd }}$ Recidivism within 1 year for Juvenile Detention Alternative Initiative Data (Table 10)

\begin{tabular}{rrrrr|}
\hline Frequency & Percent & \multicolumn{2}{c|}{ Valid } & Cumulative \\
No Recidivism & 3600 & 81.0 & 81.0 & 81.0 \\
Probation Violation & 157 & 3.5 & 3.5 & 84.6 \\
Contempt of Court & 1 & .0 & .0 & 84.6 \\
Ordinance Violation & 1 & .0 & .0 & 84.6 \\
Entering a Motor Vehicle W/Out Consent & 1 & .0 & .0 & 84.6 \\
Unlawful Application of Graffiti & 2 & .0 & .0 & 84.7 \\
Possession of Less Than 1 Oz. of & 13 & .3 & .3 & 85.0 \\
Marijuana & & & & \\
Unlawful Possession of a Weapon - & 8 & .2 & .2 & 85.2 \\
Misdemeanor & & & & \\
Carrying a Concealed Weapon & 5 & .1 & .1 & 85.3 \\
Offensive Littering & 1 & .0 & .0 & 85.3 \\
False Information to Police & 3 & .1 & .1 & 85.4 \\
Initiating a False Report & 1 & .0 & .0 & 85.4 \\
Criminal Trespass II & 57 & 1.3 & 1.3 & 86.7 \\
Criminal Mischief III & 12 & .3 & .3 & 86.9 \\
Marijuana in Public & 2 & .0 & .0 & 87.0 \\
Public Indecency & 1 & .0 & .0 & 87.0 \\
Animal Abuse II & 1 & .0 & .0 & 87.0 \\
Harassment & 18 & .4 & .4 & 87.4 \\
Disorderly Conduct & 7 & .2 & .2 & 87.6 \\
\hline
\end{tabular}


Frequency Distribution of $2^{\text {nd }}$ Recidivism within 1 year for Juvenile Detention Alternative Initiative Data (Table 10) Continued

Valid Cumulative

\begin{tabular}{|c|c|c|c|c|}
\hline $\begin{array}{ll} & \text { Perjury }\end{array}$ & 1 & .0 & .0 & 87.6 \\
\hline Obstructing Government Administration & 2 & .0 & .0 & 87.7 \\
\hline Negotiating a Bad Check & 1 & .0 & .0 & 87.7 \\
\hline Misconduct w/ Emergency Telephone & 1 & .0 & .0 & 87.7 \\
\hline \multicolumn{5}{|l|}{ Calls } \\
\hline Theft III & 51 & 1.1 & 1.1 & 88.9 \\
\hline Theft II & 69 & 1.6 & 1.6 & 90.4 \\
\hline Theft II, Attempted & 2 & .0 & .0 & 90.5 \\
\hline Forgery II & 3 & .1 & .1 & 90.5 \\
\hline Escape II & 1 & .0 & .0 & 90. \\
\hline Escape II, Attempted & 1 & .0 & .0 & 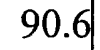 \\
\hline Criminal Possession of a Forgery & 1 & .0 & .0 & 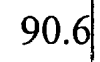 \\
\hline \multicolumn{5}{|l|}{ Instrument II } \\
\hline Resisting Arrest & 2 & .0 & .0 & 90.6 \\
\hline Reckless Burning & 1 & .0 & .0 & 90.7 \\
\hline Criminal Mischief II & 41 & .9 & .9 & 91.6 \\
\hline \multicolumn{5}{|l|}{ Attempted } \\
\hline Criminal Trespass I & 9 & .2 & .2 & 91.9 \\
\hline Menacing & 15 & .3 & .3 & 92.2 \\
\hline Unlawful Entry into a Motor Vehicle & 1 & .0 & .0 & 92.2 \\
\hline Recklessly Endangering Another Person & 5 & .1 & .1 & 92.3 \\
\hline Robbery III, Attempted & 1 & .0 & .0 & 92.3 \\
\hline Theft I, Attempted & 1 & .0 & .0 & 92.4 \\
\hline Intimidation II & 1 & .0 & .0 & 92. \\
\hline Criminal Conspiracy IV & 3 & .1 & .1 & 92. \\
\hline Assault IV & 50 & 1.1 & 1.1 & 93.6 \\
\hline Assault III, Attempted & 1 & .0 & .0 & 93.6 \\
\hline Sexual Abuse III & 1 & .0 & .0 & 93.6 \\
\hline & \multicolumn{3}{|c|}{ Felony } & 93.7 \\
\hline \multicolumn{5}{|l|}{ Instrument I } \\
\hline Theft I & 13 & .3 & .3 & 94.0 \\
\hline Possession of a Stolen Motor Vehicle & 2 & .0 & .0 & 94.1 \\
\hline Unauthorized Use of a Motor Vehicle & 64 & 1.4 & 1.4 & 95.5 \\
\hline $\begin{array}{ll}\text { Forgery I }\end{array}$ & 2 & .0 & .0 & 95.5 \\
\hline Criminal Mischief I & 27 & .6 & .6 & 96.2 \\
\hline Escape I & 2 & .0 & .0 & 96 \\
\hline
\end{tabular}

Table 10 Continued on the Next Page 
Frequency Distribution of $2^{\text {nd }}$ Recidivism within 1 year for Juvenile Detention. Alternative Initiative Data (Table 10) Continued

\begin{tabular}{rrrrr|}
\hline Burglary II & 24 & .5 & .5 & 96.7 \\
Tampering W/ a Witness & 2 & .0 & .0 & 96.8 \\
Riot & 1 & .0 & .0 & 96.8 \\
Intimidation I & 1 & .0 & .0 & 96.8 \\
Robbery III & 7 & .2 & .2 & 97.0 \\
Assault III & 18 & .4 & .4 & 97.4 \\
Criminal Simulation & 1 & .0 & .0 & 97.4 \\
Coercion & 1 & .0 & .0 & 97.4 \\
Possession of a Controlled Substance I & 2 & .0 & .0 & 97.5 \\
Possession of a Controlled Substance II & 11 & .2 & .2 & 97.7 \\
Assault III, Attempted & 1 & .0 & .0 & 97.7 \\
Assault II, Attempted & 1 & .0 & .0 & 97.8 \\
Delivery of a Controlled Substance II & 16 & .4 & .4 & 98.1 \\
Creation or Delivery of a Counterfeit & 1 & .0 & .0 & 98.2 \\
Substance II & & & & \\
Delivery of a Controlled Substance I & 5 & .1 & .1 & 98.3 \\
Burglary I, Attempted & 1 & .0 & .0 & 98.3 \\
Assault II & 5 & .1 & .1 & 98.4 \\
Robbery II & 8 & .2 & .2 & 98.6 \\
Sexual Abuse I & 3 & .1 & .1 & 98.6 \\
Sexual Misconduct & 1 & .0 & .0 & 98.7 \\
Sodomy II & 1 & .0 & .0 & 98.7 \\
Minor & 3 & .1 & .1 & 98.8 \\
Burglary I & 41 & .9 & .9 & 99.7 \\
Arson I & 2 & .0 & .0 & 99.7 \\
Criminal Conspiracy I & 1 & .0 & .0 & 100.0 \\
Unknown & 1 & .0 & .0 & 100.0 \\
Total & 4442 & 100.0 & 100.0 & \\
Kelivering a Controlled Substance to a & 1 & .0 & .0 & 99.8 \\
Assault I & 1 & .0 & .0 & 99.8 \\
Robbery I & 3 & .0 & .0 & 99.8 \\
Rape I & 2 & .0 & .1 & 99.9 \\
Sexual Penetration W/ a Foreign Object I & 1 & & & Table 10
\end{tabular}

The next tables provide the same information as the previous tables, except they pertain to third offenses within a one year period of time. $97.6 \%$ of offenders are not charged with a third offense in the Resolutions Northwest group. $92.7 \%$ of the 
offenders in the Juvenile Detention Alternative Initiative group did not have a third charge on their records. Table 11 and Table 12 show this information in its entirety.

3rd Recidivism within 1 year of Completion of Resolutions Northwest VictimOffender Mediation Program - Frequency Distribution

\begin{tabular}{|rrrrr|}
\hline & Frequency & Percent & Valid Percent & Cumulative Percent \\
No Recidivism & 245 & 97.6 & 97.6 & 97.6 \\
Theft III & 1 & .4 & .4 & 98.0 \\
Criminal Mischief II & 2 & .8 & .8 & 98.8 \\
Unauthorized Use of a & 3 & 1.2 & 1.2 & 100.0 \\
Motor Vehicle & & & & \\
Total & 251 & 100.0 & 100.0 & \\
\hline
\end{tabular}

Table 11

Frequency Distribution of 3rd Recidivism within 1 year for Juvenile Detention Alternative Initiative Data (Table 12)

\begin{tabular}{|c|c|c|c|c|}
\hline & Frequency & Percent & $\begin{array}{r}\text { Valid } \\
\text { Percent }\end{array}$ & $\begin{array}{r}\text { Cumulative } \\
\text { Percent }\end{array}$ \\
\hline No Recidivism & 4116 & 92.7 & 92.7 & \\
\hline Probation Violation & 59 & 1.3 & 1.3 & \\
\hline Ordinance Violation & 1 & .0 & .0 & \\
\hline Entering a Motor Vehicle w/out Consent & 1 & .0 & .0 & \\
\hline $\begin{array}{r}\text { Possession of Less than } 1 \mathrm{Oz} \text {. of } \\
\text { Marijuana }\end{array}$ & 3 & .1 & .1 & \\
\hline $\begin{array}{r}\text { Unlawful Possession of a Weapon - } \\
\text { Misdemeanor }\end{array}$ & 4 & .1 & .1 & \\
\hline Offensive Littering & 1 & .0 & .0 & \\
\hline Carrying a Concealed Weapon & 35 & .8 & .8 & \\
\hline Criminal Mischief III & 2 & .0 & .0 & \\
\hline Harassment & 7 & .2 & .2 & \\
\hline Disorderly Conduct & 5 & .1 & .1 & \\
\hline Theft of Services & 1 & .0 & .0 & \\
\hline Theft III & 24 & .5 & .5 & \\
\hline Theft II & 25 & .6 & .6 & \\
\hline Forgery II & 2 & .0 & .0 & \\
\hline Resisting Arrest & 1 & .0 & .0 & \\
\hline Reckless Burning & 1 & .0 & .0 & \\
\hline Criminal Mischief II & 18 & .4 & .4 & \\
\hline $\begin{array}{r}\text { Unauthorized Use of a Motor Vehicle - } \\
\text { Attempted }\end{array}$ & 1 & .0 & .0 & \\
\hline Criminal Trespass I & 1 & .0 & .0 & \\
\hline Menacing & 8 & .2 & .2 & \\
\hline
\end{tabular}

Table 12 Continued on the Next Page 
Frequency Distribution of 3rd Recidivism within 1 year for Juvenile Detention Alternative Initiative Data (Table 12) Continued

Valid Cumulative

\begin{tabular}{|c|c|c|c|c|}
\hline & & & & \\
\hline Burglary II, Attempted & 1 & .0 & .0 & 97.2 \\
\hline Recklessly Endangering Another Person & 4 & .1 & .1 & 97.3 \\
\hline Criminal Conspiracy IV & 2 & .0 & .0 & 97.3 \\
\hline Assault IV & 20 & .5 & .5 & 97.8 \\
\hline $\begin{array}{r}\text { Unlawful Possession of a Weapon - } \\
\text { Felony }\end{array}$ & 1 & .0 & .0 & 97.8 \\
\hline Theft I & 6 & .1 & .1 & 97.9 \\
\hline Unauthorized Use of a Motor Vehicle & 22 & .5 & .5 & 98.4 \\
\hline $\begin{array}{ll}\text { Forgery I }\end{array}$ & 1 & .0 & .0 & 98.4 \\
\hline Criminal Mischief I & 7 & .2 & .2 & 98.6 \\
\hline Unlawful Use of a Weapon & 1 & .0 & .0 & 98.6 \\
\hline Burglary II & 7 & .2 & .2 & 98.8 \\
\hline Criminal Conspiracy III & 3 & .1 & .1 & 98.9 \\
\hline Intimidation I & 3 & .1 & .1 & 98.9 \\
\hline $\begin{array}{lll}\text { Assault III }\end{array}$ & 5 & .1 & .1 & 99.0 \\
\hline Possession of a Controlled Substance I & 2 & .0 & .0 & 99.1 \\
\hline Possession of a Controlled Substance II & 4 & .1 & .1 & 99.2 \\
\hline Delivery of a Controlled Substance II & 7 & .2 & .2 & 99.3 \\
\hline Delivery of a Controlled Substance I & 1 & .0 & .0 & 99.3 \\
\hline Burglary I, Attempted & 1 & .0 & .0 & 99.4 \\
\hline Assault II & 1 & .0 & .0 & 99.4 \\
\hline Robbery II & 2 & .0 & .0 & 99.4 \\
\hline Kidnapping I & 1 & .0 & .0 & 99.5 \\
\hline $\begin{array}{r}\text { Delivering a Controlled Substance to a } \\
\text { Minor }\end{array}$ & 1 & .0 & .0 & 99.5 \\
\hline Burglary I & 20 & .5 & .5 & 99.9 \\
\hline Assault I & 1 & .0 & .0 & 100.0 \\
\hline Robbery I & 1 & .0 & .0 & 100.0 \\
\hline Criminal Conspiracy I & 1 & .0 & .0 & 100.0 \\
\hline Total & 4442 & 100.0 & 100.0 & \\
\hline
\end{tabular}

Table 12

Finally, the gap closes even further when viewing the tables on fourth offenses within a one year period. $99.6 \%$ of the Resolutions Northwest group did not show a fourth crime on their records. Table 13 details this information. Table 14 shows that 
the Juvenile Detention Alternative Initiative juveniles were not far behind with 98:1\% of the group lacking a fourth offense on their records.

4th Recidivism within 1 year of Completion of Resolutions Northwest Victim Offender Mediation Program - Frequency Distribution

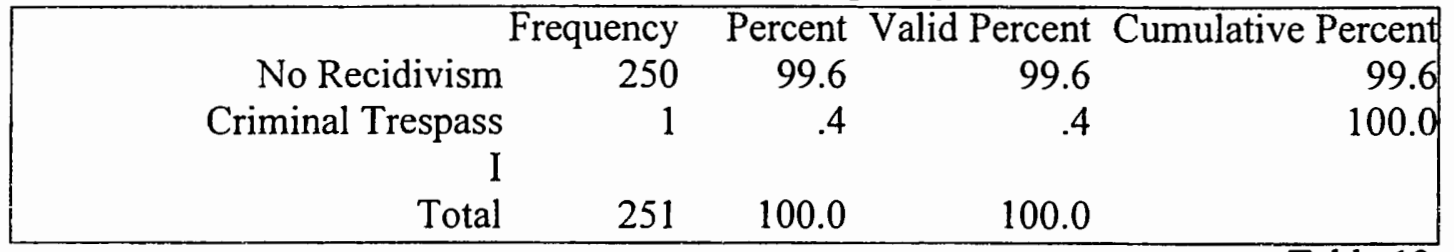

Table 13

Frequency Distribution of 4th Recidivism within 1 year for Juvenile Detention Alternative Initiative Data (Table 14)

\begin{tabular}{rrrrr}
\hline Frequency & Percent & \multicolumn{2}{r|}{ Valid } & Cumulative \\
No Recidivism & 4359 & 98.1 & 98.2 & 98.2 \\
Probation Violation & 14 & .3 & .3 & 98.5 \\
Consent & 1 & .0 & .0 & 98.5 \\
Entering a Motor Vehicle w/out & & & & \\
Marijuana & 3 & .1 & .1 & 98.6 \\
Possession of Less Than 1 Oz. of & & & & \\
Criminal Trespass II & 8 & .2 & .2 & 98.8 \\
Criminal Mischief III & 1 & .0 & .0 & 98.8 \\
Harassment & 1 & .0 & .0 & 98.8 \\
Disorderly Conduct & 3 & .1 & .1 & 98.9 \\
Theft III & 8 & .2 & .2 & 99.1 \\
Theft II & 3 & .1 & .1 & 99.1 \\
Criminal Mischief II & 1 & .0 & .0 & 99.2 \\
Menacing & 2 & .0 & .0 & 99.2 \\
Assault IV & 3 & .1 & .1 & 99.3 \\
Theft I & 1 & .0 & .0 & 99.3 \\
Vehicle & 4 & .1 & .1 & 99.4 \\
Burglary II & 3 & .1 & .1 & 99.5 \\
Criminal Mischief & 6 & .1 & .1 & 99.6 \\
Assault III & 1 & .0 & .0 & 99.6 \\
Tampering w/ a Wittess & 1 & .0 & .0 & 99.6 \\
II & 1 & .0 & .0 & 99.7 \\
Possession of a Controlled Substance & & & & \\
II & 1 & .0 & .0 & 99.7 \\
Delivery of a Controlled Substance & & & & \\
\hline
\end{tabular}

Table 14 Continued on the Next Page 
- Frequency Distribution of 4th Recidivism within 1 year for Juvenile Detention • Alternative Initiative Data (Table 14) Continued

\begin{tabular}{|c|c|c|c|c|c|}
\hline & & Frequency & Percent & $\begin{array}{r}\text { Valid } \\
\text { Percent } \\
\end{array}$ & $\begin{array}{r}\text { Cumulative } \\
\text { Percent }\end{array}$ \\
\hline & Burglary I, Attempted & 1 & .0 & .0 & .99 .7 \\
\hline & Robbery II & 2 & .0 & .0 & 99.8 \\
\hline & Burglary I & 10 & .2 & .2 & 100.0 \\
\hline & Robbery I & 1 & .0 & .0 & 100.0 \\
\hline & Total & 4439 & 99.9 & 100.0 & \\
\hline & Missing Record & 3 & .1 & & \\
\hline Total & & 4442 & 100.0 & & \\
\hline
\end{tabular}

Table 14

Now that first through fourth offenses within a one year period have been looked at individually, it is beneficial to examine the rates together. This will make comparison purposes much more concise. Table 15 below shows the rates of recidivism for both the Resolutions Northwest and the Juvenile Detention Alternative Initiative data in one succinct table.

Recidivism Rates for Resolutions Northwest (RNW) and Juvenile Detention Alternative Initiative (JDAI) Data

\begin{tabular}{|l|c|c|c|c|}
\multicolumn{5}{c}{ Number and Percent Recidivating } \\
\hline & $\mathrm{N}$ & $\%$ & $\mathrm{~N}$ & $\%$ \\
\hline $1^{\text {st }}$ Offense in 1 year & 51 & $20.3 \%$ & 1848 & $41.6 \%$ \\
\hline $2^{\text {nd }}$ Offense in 1 year & 16 & $6.4 \%$ & 842 & $19 \%$ \\
\hline $3^{\text {rd }}$ Offense in 1 year & 6 & $2.4 \%$ & 326 & $7.3 \%$ \\
\hline $4^{\text {th }}$ Offense in 1 year & 1 & $0.4 \%$ & 83 & $1.8 \%$ \\
\hline
\end{tabular}

Looking at Table 15 , it is quite clear that only $20.3 \%$ of the juvenile offenders who went through Resolutions Northwest's victim-offender mediation program 
reoffended. That is only about 1 out of every 5 offenders. When comparing this to the Juvenile Detention Alternative Initiative group, it is found that $41.6 \%$ of the young offenders recidivated. That means that slightly more than 2 out of every 5 juvenile offenders recidivated in that group.

Table 15 shows that both groups massively funnel down in the number of youths who reoffended a second, third or fourth time. However, Resolutions Northwest's offenders show a marked improvement over the Juvenile Detention Alternative Initiative offenders in this respect. The rates of whether or not the Juvenile Detention Alternative Initiative group reoffends a second time is roughly comparable to whether the Resolutions Northwest group recidivated the first time, coming in at $19 \%$ and $20.3 \%$ respectively.

In fact, the Juvenile Detention Alternative Initiative group proves to have rates at more than double the Resolutions Northwest offenders for the first, second, third and fourth reoffenses. The largest disparity between the groups does come with the second reoffense, however. Roughly 1 out of every $5(19 \%)$ juvenile offenders in the Juvenile Detention Alternative Initiative group went on to reoffend twice. Only $6.4 \%$ of the Resolutions Northwest group reoffended twice.

For further clarification, Table 16 will show similar information to that in Table 15. However, Table 16 shows the rates that both the Resolutions Northwest juvenile offenders and the Juvenile Detention Alternative Initiative group did not reoffend. Therefore, Table 16 gives a reverse look at the recidivism rates. In other words, Table 16 looks at the offenders in both groups who went through the entire 
year after their original arrests that brought them to the justice system without being arrested again.

Rates for Those Without Reoffenses from the Resolutions Northwest.(RNW) and Juvenile Detention Alternative Initiative (JDAI) Data

Number and Percent Not Recidivating

\begin{tabular}{|c|c|c|c|c|}
\hline & \multicolumn{2}{|c|}{ RNW } & \multicolumn{2}{|c|}{ JDAI } \\
\hline & $\bar{N}$ & $\%$ & $\bar{N}$ & $\%$ \\
\hline No $1^{\text {st }}$ Offense & 200 & $79.7 \%$ & 2594 & $58.4 \%$ \\
\hline No $2^{\text {nd }}$ Offense & 235 & $93.6 \%$ & 3600 & $81.0 \%$ \\
\hline No $3^{\text {rd }}$ Offense & 245 & $97.6 \%$ & 4116 & $92.7 \%$ \\
\hline No $4^{\text {th }}$ Offense & 250 & $99.6 \%$ & 4359 & $98.2 \%$ \\
\hline
\end{tabular}

Table 16

Table 16 above concludes this analysis of Resolutions Northwest's recidivism rates. As can be seen above, there clearly are a significantly higher number of juvenile offenders who do not reoffend within the first year after completion of Resolutions Northwest's victim-offender mediation program. It does appear that (for offenders, at least) Resolution Northwest's victim-offender mediation program is highly beneficial to the rehabilitative process of the juvenile offenders who participate in it.

However, caution should be used when looking at this analysis of Resolutions Northwest's recidivism rates. Although the lower recidivism rates reported within this thesis do show remarkable achievement for Resolutions Northwest, they alone cannot be used to gauge the true success of a victim-offender mediation program or any program or service within the justice system. There are too many other factors involved in the evaluation of a program to use recidivism alone to weigh success. 
It also should be noted when looking at Resolutions Northwest's lower $\quad$. recidivism rate that there are limitations to the conclusions. The possibility does exist that the juvenile offenders who are referred to Resolutions Northwest have only been referred because it was believed that they had a greater chance of avoiding recidivism in the first place. This factor alone could account for the lower recidivism rate with the victim-offender mediation program having no effect whatsoever.

Limitations aside, Resolutions Northwest's juvenile offenders do show a significantly lower recidivism rate than the adjudicated juvenile offenders they were compared to. Avoiding recidivism and staying out of the justice system will certainly impact the young people who went through Resolutions Northwest's victim-offender mediation program in a positive way. It could be argued that this kind of positive impact in a juvenile's life is all that is necessary to call Resolutions Northwest's program a success. 


\section{Works Cited}

Bazemore, G. \& M.S. Umbreit. 1994. Balanced and Restorative Justice Program Summary. Washington, DC: US Department of Justice, Office of Justice Programs, Office of Juvenile Justice and Delinquency Prevention.

Bazemore, Gordon \& M. S. Umbreit. 1998. Conferences, Circles, Boards, and Mediations: Restorative Justice and Citizen Involvement in Response to Youth Crime. Washington, DC: US Department of Justice, Office of Juvenile Justice and Delinquency Prevention.

Bradshaw, W. and M. Umbreit. 1998. Crime Victims Meet Juvenile Offenders: Contributing Factors to Victim Satisfaction with Mediated Dialogue, Juvenile and Family Counseling Journal Vol 49 (Summer 1998) pp. 17-25.

Carr, C. 1998. VORS Program Evaluation Report.

Clarke, S., E. Valente, Jr., and R. Mace. 1992. Mediation of Interpersonal Disputes: An Evaluation of North Carolina's Programs. Chapel Hill: Institute of Government, University of North Carolina.

Collins, J.P. 1984. Final Evaluation Report on the Grande Prairie Community Reconciliation Project for Young Offenders.

Conflict Resolution. Pamphlet: Resolutions Northwest.

Flaten, C. 1996. Victim Offender Mediation: Application with Serious Offences Committed by Juveniles. In: B. Galaway and J. Hudson (eds.), Restorative Justice: International Perspectives. Monsey, NY: Criminal Justice Press, pp. 387-401.

Gehm, J. 1990. Mediated Victim-Offender Restitution Agreements: An Exploratory Analysis of Factors Related to Victim Participation. In B. Galaway and J. Judson (eds.), Criminal Justice, Restitution, and Reconciliation. Monsey, NY: Criminal Justice Press, pp. 177-182.

Hughes, S. and A. Schneider. 1990. Victim-Offender Mediation in the Juvenile Justice System. Washington, D.C.: Office of Juvenile Justice and Delinquency Prevention.

Marshall, T. 1998. Restorative Justice for Victims, Communties and Offenders. St. Paul, MN: University of Minnesota.

Niemeyer, M. and D. Shichor. 1996. A Preliminary Study of a Large Victim/Offender Reconciliation Program, Federal Probation Vol. 60 (September). 
Nugent, W. and J. Paddock. 1995. The Effect of Victim-Offender Mediation on Severity of Reoffense, Mediation Quarterly Vol. 12, Summer, pp. 353-367.

Nugent, W., M. Umbreit, L. Wiinamaki, and J. Paddock. 2000. Participation in Victim-Offender Mediation and Severity of Subsequent Delinquent Behavior: Successful Replication? Journal of Research in Social Work Practice.

Roberts, L. 1998. Victim Offender Mediation: An Evaluation of the Pima County Juvenile Court Center's Victim Offender Mediation Program (VOMP). Available from Frasier Area Community Justice Initiatives in Langley, British Columbia.

Roy, S. 1993. Two Types of Juvenile Restitution Programs in Two Midwestern Counties: A Comparative Study, Federal Probation Vol. 57, pp. 48-53.

Schiff, M. F. 1998. Restorative Justice Interventions for Juvenile Offenders: A Research Agenda for the Next Decade. Western Criminology Review 1(1). [Online]. Available: http://wcr.sonoma.edu/v1n1/schiff.html.

Schneider, A. 1986. Restitution and Recidivism Rates of Juvenile Offenders: Results from Four Experimental Studies, Criminology Volume 24, pp. 533-552.

Umbreit, M.S. 1988. Mediation of Victim Offender Conflict, Journal of Dispute Resolution, pp. 85-105.

Umbreit, M. 1989. Crime Victims Seeking Fairness, Not Revenge: Toward

Restorative Justice, Federal Probation (September 1989) pp. 52-57.

Umbreit, M. 1989. Violent Offenders and Their Victims. In: M. Wright and B. Galaway (eds.) Mediation and Criminal Justice. London: Sage, pp. 99-112.

Umbreit, M. 1990. Minnesota Mediation Center Produces Positive Results, Corrections Today (August) pp. 194-197.

Umbreit, M. 1992. Program Evaluation Kit: Victim Offender Mediation Programs. Minneapolis, MN: Minnesota Citizens Council of Crime and Justice.

Umbreit, M. 1995. Mediation of Criminal Conflict: An Assessment of Programs in Four Canadian Provinces. St. Paul, MN: Center for Restorative Justice and Mediation.

Umbreit, M.S. \& Bradshaw, W. 1997. Victim Experience of Meeting Adult vs. Juvenile Offenders: A Cross-National Comparison. Federal Probation. 61(4):33-39. 
Umbreit, M.S. \& Coates, R.B. 1992. Victim Offender Mediation: An Analysis of Programs in Four States of The U.S. St. Paul, MN: Center for Restorative Justice and Mediation University of Minnesota.

Umbreit, M.S. \& Robert Coates, Boris Kalanj, Rachel Lipkin, and George Petros. 1995. Mediation of Criminal Conflict: An Assessment of Programs in Four Canadian Provinces. St. Paul, MN: University of Minnesota.

Umbreit, M.S. \& Coates, Robert. 1998. Multi-Cultural Implications of Restorative Justice: Potential Pitfalls and Dangers. Washington, DC: Office of Victims of Crime, US Dept. of Justice.

Umbreit, M.S. \& Greenwood, J. 1997. Criteria for Victim-Sensitive Mediation and Dialogue with Offenders. Washington, DC: Office of Victims of Crime, US Dept. of Justice.

Umbreit, M.S. \& Greenwood, J. 1997. National Survey of Victim Offender Mediation Programs in the US. Washington DC: Office of Victims of Crime, US Department of Justice.

Umbreit, M.S. \& Roberts, Ann Warner. 1996. Mediation of Criminal Conflict in England: An Assessment of Services in Coventry and Leeds. St. Paul, MN: University of Minnesota.

Umbreit, M. \& Vos, Betty. 2000. Homicide/Survivors Meet the Offender Prior to Execution: Restorative Justice Through Dialogue. Homicide Studies.

Van Ness, Daniel \& Strong, Karen Heetderks. 1997. Restoring Justice. Cincinnati, $\mathrm{OH}$ : Anderson Publishing Co.

Volpe, Maria R. 1991. Mediation in the Criminal Justice System: Process, Promises, Problems. In Harold E. Pepinsky and Richard Quinney (eds.), Criminology as Peacemaking. Bloomington, IN: Indiana University Press. 